\title{
Pengaruh Beban Kerja Terhadap Kelelahan Kerja (Studi Kasus pada Karyawan PT. Adira Dinamika Multi Finance Cabang Muara Bungo)
}

\author{
Ratumas Hartha Delima ${ }^{1}$ \\ STIE Graha Karya Muara Bulian ${ }^{1}$ \\ Ratuartha89@gmail.com
}

\begin{abstract}
The purpose of this study was to determine how the influence of workload on work fatigue collection and marketing at PT. Adira Dinamika Multi Finance, Muara Bungo. The independent variable is the workload and the dependent variable is work fatigue. This type of research is a quantitative approach. The scale of measurement of variables in this study is using Likert scale. In this study the population is the collection and marketing employees at PT. Adira Dinamika Multi Finance, Muara Bungo which amounted to 32 people. Data analysis method in this research use simple linear regression. Based on the results of data processing, partial test results of workload variables on work fatigue have $t$-count $>$ t-table of 9.706> 2.042, then the decision is Ho rejected and Ha accepted means that the workload variable has an effect on employee fatigue part collection and marketing at PT. Adira Dinamika Multi Finance, Muara Bungo. Thus the higher the workload given the company will increase employee fatigue. The result of determination test $(R 2)$ can be concluded that having the ability of work load variable to explain the variation of employee fatigue variable is 75,8\%. This shows that the work fatigue of employees of a company can increase if the workload given by the company is high. For $24.2 \%$ can be explained by other factors outside of this study.
\end{abstract}

Keywords: workload, work fatigue

\section{PENDAHULUAN}

Pembangunan

ketenagakerjaan dilaksanakan dalam rangka pembangunan manusia Indonesia seutuhnya berdasarkan Pancasila dan Undang-Undang Dasar 1945 guna mewujudkan manusia dan masyarakat Indonesia yang sejahtera, adil, makmur dan merata baik materil maupun spiritual. Pembangunan ketenagakerjaan ditujukan untuk peningkatan, pembentukan, dan pengembangan tenaga kerja yang berkualitas dan produktif. Kebijakan yang mendorong tercapainya pembangunan ketenagakerjaan adalah perlindungan tenaga kerja (Budiono, 2003). Perlindungan tenaga kerja meliputi aspek yang cukup luas yaitu perlindungan keselamatan, kesehatan, pemeliharaan moral kerja serta perlakuan yang sesuai dengan martabat manusia dan moral bangsa. Perlindungan tersebut bertujuan untuk memberikan jaminan keselamatan dan meningkatkan derajat kesehatan para pekerja. Tujuan dari kesehatan kerja yaitu untuk menciptakan tenaga kerja yang sehat dan produktif. Tujuan kesehatan kerja dapat tercapai apabila didukung oleh lingkungan kerja yang memenuhi syaratsyarat kesehatan. Salah satu tujuan dari pelaksanaan kesehatan kerja dalam bentuk operasional adalah pencegahan kelelahan dan meningkatakan kegairahan serta nikmat kerja (Suma'mur, 2009).

Tubuh manusia dirancang untuk dapat melakukan aktivitas pekerjaan sehari-hari. Adanya massa otot yang bobotnya hampir lebih dari separuh dari berat tubuh, memungkinkan manusia untuk dapat menggerakkan tubuh dan melakukan pekerjaan. Pekerjaan disatu pihak mempunyai arti penting bagi kemajuan dan peningkatan prestasi, sehingga dapat mencapai kehidupan yang produktif sebagai salah satu tujuan hidup. Dipihak 
lain, dengan bekerja berarti tubuh akan menerima beban dari luar tubuhnya. Dengan kata lain bahwa setiap pekerja merupakan beban bagi yang bersangkutan. Beban tersebut dapat berupa beban fisik maupun beban mental. Menurut Meshkati dalam Tarwaka (2010), beban kerja didefinisikan sebagai suatu perbedaan antara kapasitas atau kemampuan pekerja dengan tuntutan pekerjaan yang harus dihadapi.

Menurut Suma'mur (2009), beban kerja merupakan kemampuan kerja seorang tenaga kerja berbeda dari satu kepada yang lainnya dan sangat tergantung dari tingkat ketrampilan, kesegaran jasmani, keadaan gizi, jenis kelamin, usia dan ukuran tubuh dari pekerja yang bersangkutan. Kelelahan adalah keadaan yang disertai penurunan efisiensi dan ketahanan dalam bekerja. Kata kelelahan menunjukkan keadaan yang berbeda-beda, tetapi semuanya berakibat kepada pengurangan kapasitas kerja dan ketahanan tubuh. Jadi efek pajanan bising pada tenaga kerja adalah pengaruhnya terhadap kesehatan dan kinerjanya. Beberapa diantaranya adalah gangguan pendengaran, komunikasi, kelelahan, respon fisiologis dan psikologis (Tarwaka, 2010).

PT. Adira Dinamika Multi Finance Cabang Muara Bungo merupakan perusahaan pembiayaan yang melayani pembiayaan terhadap pembelian kendaraan bermotor dan mobil serta produk elektronik. Dalam menjalankan usahanya PT. Adira Dinamika Multi Finance Cabang Muara Bungo menetapkan beban kerja melalui target pembiayaan yang harus dicapai oleh karyawan. Beban waktu yang dirasakan oleh bagian marketing dan collection terkadang tidak cukup untuk menyelesaikan pekerjaan mereka, hal ini dikarenakan target ditentukan setiap bulan semesteran, dan tahunan, hal ini sebagaimana yang disampaikan Bapak Awaludin selaku Kepala Bagian Personalia di Kantor Adira Dinamika Multi Cabang Muara Bungo.

Beban usaha mental yang dialami karyawan bagian marketing dan collection cukup berat, dikarenakan pekerjaan mereka memerlukan usaha mental yang cukup tinggi, hal ini dikarenakan apabila karyawan tersebut tidak memuhi target yang telah ditetapkan maka akan berdampak pada insentif yang diterima oleh karyawan tersebut, dampak lainnya juga akan mempengaruhi jenjang karir dari karyawan itu sendiri. Selain itu beban tekanan psikologi juga dialami karyawan bagian marketing dan collection PT. Adira Dinamika Multi Finance Cabang Muara Bungo, kondisi ini dikarenakan jika pencapaian jauh dari target yang ditetapkan maka karyawan tersebut akan mendapatkan teguran tertulis dari bagian personalia, teguran tersebut berjenjang hingga mutasi dan pemberhentian kontrak kerja. Berikut merupakan target pembiayaan konsumen PT. Adira Dinamika Multi Finance Cabang Muara Bungo tahun 2011-2016.

Tabel 1. Pencapaian Target Pembiayaan

Konsumen PT. Adira Dinamika Multi

Finance Cabang Muara Bungo 2011-2016

\begin{tabular}{cccc}
\hline Th & $\begin{array}{c}\text { Target } \\
\text { Biaya }\end{array}$ & $\begin{array}{c}\text { Realisasi } \\
\text { biaya }\end{array}$ & $\%$ \\
\hline 2011 & 650 & 683 & 105,08 \\
2012 & 855 & 749 & 87,60 \\
2013 & 1045 & 878 & 84,02 \\
2014 & 1160 & 1295 & 111,64 \\
2015 & 1300 & 1215 & 93,46 \\
2016 & 1350 & 1268 & 93,93 \\
\hline
\end{tabular}

Sumber : PT. Adira Dinamika Multi

Finance Cabang Muara Bungo, 2017

Berdasarkan tabel di atas, dapat terlihat bahwa hampir setiap tahunnya target pembiayaan konsumen mendekati $100 \%$, meskipun kondisi perekonomian Indonesia belum baik, khususnya perekonomian masyarakat Kabupaten Bungo namun pencapaian target kerja yang dibebankan kepada karyawan hampir 
terpenuhi dengan baik. Dengan kondisi harga karet yang fluktuatif menyebabkan daya beli masyarakat menurun, hal ini juga berakibat pada menurunnya minat masyarakat dalam membeli kendaraan, sehingga mempengaruhi target pembiayaan yang ditetapkan PT. Adira Dinamika Multi Finance Cabang Muara Bungo.

Bagian marketing merupakan bagian terpenting dari suatu perusahaan. Karyawan yang bekerja pada bagian marketing memiliki jam kerja yang tinggi dan membutuhkan kesabaran dalam melaksanakan pekerjaannya. Selain itu untuk bagian marketing, pencapaian target dalam jumlah tertentu juga memberikan tekanan kepada karyawan karena umumnya pencapaian target tersebut ditentukan dalam batas waktu tertentu ditambah lagi untuk menyelesaikan pekerjaannya terkadang harus dilakukan di luar jam kerja.

Berdasarkan observasi dan wawancara peneliti dengan karyawan bagian marketing pada PT. Adira Dinamika Multi Finance Cabang Muara Bungo diketahui bahwa sering terjadi kelelahan kerja pada karyawan, hal ini terlihat dari menurunya kegiatan mental dan fisik pada karyawan, seperti mudah mengantuk saat bekerja. Kondisi lainnya adalah menurunnya perhatian karyawan yang disebabkan kelelahan akibat pekerjaan. Serta kemampuan berprestasi karyawan yang menurun, padahal perusahaan telah mengukur beban kerja dengan kemampuan kerja karyawan.

\section{KAJIAN TEORI}

Beban Kerja. Menurut Tarwaka (2010) beban kerja merupakan suatu yang muncul dari interaksi antara tuntutan tugas-tugas lingkungan kerja dimana digunakan sebagai tempat kerja, keterampilan dan persepsi dari pekerja. Setiap pekerja dapat bekerja secara sehat tanpa membahayakan dirinya sendiri maupun masyarakat di sekelilingnya, untuk itu perlu dilakukan upaya penyerasian antara kapasitas kerja, beban kerja dan lingkungan kerja agar, sehingga diperoleh produktivitas kerja yang optimal (UU Kesehatan No 36 Tahun 2009).

Menurut Munandar (2001) beban kerja adalah suatu kondisi dari pekerjaan dengan uraian tugasnya yang harus diselesaikan pada batas waktu tertentu. Beban kerja dapat dibedakan lebih lanjut ke dalam beban kerja berlebihan/terlalu sedikit 'kuantitatif, yang timbul sebagai akibat dari tugas-tugas yang terlalu banyak/sedikit diberikan kepada tenaga kerja untuk diselesaikan dalam waktu tertentu, dan beban kerja berlebihan/terlalu sedikit 'kualitatif', yaitu jika orang merasa tidak mampu untuk melakukan suatu tugas, atau tugas tidak menggunakan ketrampilan dan/atau potensi dari tenaga kerja.

Dengan dikemukakannya beberapa definisi di atas, maka dapat ditarik kesimpulan bahwa beban kerja adalah sebuah proses yang dilakukan oleh seseorang dalam menyelesaikan tugastugas suatu pekerjaan atau kelompok jabatan yang dilaksanakan dalam keadaan normal dalam suatu jangka waktu tertentu. Beban kerja merupakan sejauh mana kapasitas individu pekerja dibutuhkan dalam menyelesaikan tugas yang diberikan kepadanya, yang dapat diindikasikan dari jumlah pekerjaan yang harus dilakukan, waktu/batasan waktu yang dimiliki oleh pekerja dalam menyelesaikan tugasnya, serta pandangan subjektif individu tersebut sendiri mengenai pekerjaan yang diberikan kepadanya.

$$
\text { Menurut Tarwaka }
$$
pengukuran kerja bisa dilakukan melalui pengukuran kerja mental secara subjektif (Subjective Methode) salah satunya menggunakan teknik Beban Kerja Subjectif (Subjective Workload Assesment technique-SWAT), berdasarkan metode SWAT performasi kerja manusia maka indikator beban kerja antara lain ; (1) Beban waktu (time load) menunjukan jumlah waktu yang tersedia dalam 
perencanaan, pelaksanaan dan monitoring tugas atau kerja. Beban waktu juga mencakup ada atau tidaknya waktu luang, interupsi, dan overlap (kelebihan aktivitas), melihat sejauhmana beban kerja yang diberikan pimpinan terhadap jumlah jam kerja yang efektif dalam menyelesaikan tugas pekerjaannya. Agar tidak terjadi kelebihan maupun kekurangan waktu dalam menyelesaikan tugas. (2) Beban usaha mental (mental effort load) yaitu berarti banyaknya usaha mental dalam melaksanakan suatu pekerjaan. Beban usaha mental juga berkenaan dengan kesadaran dan konsentrasi dalam bekerja. (3) Beban tekanan Psikologis (psychological stress load) yang menunjukan tingkat resiko pekerjaan, kebingungan, dan frustasi.

Kelelahan Kerja. Kelelahan merupakan mekanisme perlindungan tubuh agar tubuh menghindari kerusakan lebih lanjut, sehingga dengan demikian terjadilah pemulihan (Suma'mur, 2009). Kelelahan menunjukkan kondisi yang berbeda-beda dari setiap individu, tetapi semuanya bermuara pada kehilangan efisiensi dan penurunan kapasitas kerja serta ketahanan tubuh (Tarwaka, 2010). Kelelahan adalah aneka keadaan yang disertai penurunan efisiensi dan ketahanan dalam bekerja (Suma'mur, 2009). Kelelahan kerja akan menurunkan kinerja dan menambah tingkat kesalahan kerja (Nurmianto, 2003).

Menurut Cameron kelelahan kerja merupakan kriteria yang kompleks yang tidak hanya menyangkut kelelahan fisiologis dan psikologis tetapi dominan hubungannya dengan penurunan kinerja fisik, adanya perasaan lelah, penurunan motivasi dan penurunan produktivitas kerja (Ambar, 2006). Kelelahan kerja (job bournout) adalah sejenis stress yang banyak dialami oleh orang-orang yang bekerja dalam pekerjaan-pekerjaan pelayanan terhadap manusia lainnya seperti perawat kesehatan, transportasi, kepolisian, dan sebagainya Schuler dalam Nurmianto (2003).

Menurut Mc Farland kelelahan kerja merupakan suatu kelompok gejala yang berhubungan dengan adanya penurunan efisiensi kerja, keterampilan serta peningkatan kecemasan atau kebosanan Nurmianto (2003). Kelelahan kerja ditandai oleh adanya perasaan lelah, output menurun, dan kondisi fisiologis yang dihasilkan dari aktivitas terus-menerus Nurmianto (2003). Kelelahan akibat kerja sering kali diartikan sebagai menurunnya efisiensi, performans kerja dan berkurangnya kekuatan/ketahanan fisik tubuh untuk terus melanjutkan yang harus dilakukan (Wignjosoebroto, 2000).

Suma'mur (2009) memaparkan bahwa tanda-tanda kelelahan yang utama adalah hambatan terhadap fungsi-fungsi kesadaran otak dan perubahan-perubahan pada organ-organ di luar kesadaran serta proses pemulihan. Adapun indikator kelelahan kerja adalah sebagai berikut; (1) Perhatian yang menurun yakni kelelahan dapat diketahui dari menurunya perhatian yang diakibatkan perasaan berat di kepala, menjadi lelah seluruh badan, kaki merasa berat, sering menguap, merasa kacau pikiran, manjadi mengantuk, marasakan beban pada mata, kaku dan canggung dalam gerakan, tidak seimbang dalam berdiri, mau berbaring. (2) Persepsi melambat dan menghambat seperti merasa susah berpikir, lelah berbicara, menjadi gugup, tidak berkonsentrasi, tidak dapat mempunyai perhatian terhadap sesuatu, cenderung untuk lupa, kurang kepercayaan, cemas terhadap sesuatu, tidak dapat mengontrol sikap, tidak dapat tekun dalam pekerjaan. (3) Kemampuan berprestasi menurun yaitu pekerja yang mengalami kelelahan kerja akan berprestasi lebih buruk lagi daripada pekerja yang masih "penuh semangat. (4) Kegiatan mental dan fisik menjadi kurang efisien yakni kelelahan adalah aneka keadaan yang disertai penurunan efisiensi dan ketahanan dalam bekerja. Kelelahan 
kerja akan menurunkan kinerja dan menambah tingkat kesalahan kerja, sehingga membuat kegiatan mental dan fisik menjadi kurang efesien.

Adapun yang menjadi tujuan penelitian yang ingin dicapai yaitu untuk mengetahui bagaimanakah pengaruh beban kerja terhadap kelelahan kerja karyawan collection dan marketing pada PT. Adira Dinamika Multi Finance Cabang Muara Bungo.

\begin{tabular}{|c|c|}
\hline $\begin{array}{l}\text { Beban Kerja } \\
\text { (X) }\end{array}$ & $\begin{array}{l}\text { Kelelahan } \\
\text { Kerja (Y) }\end{array}$ \\
\hline
\end{tabular}

Gambar 1. Kerangka Konseptual

\section{METODE PENELITIAN}

Jenis penelitian ini adalah pendekatan kuantitatif, karena penelitian ini disajikan dengan angka-angka. Hal ini sesuai dengan pendapat (Arikunto 2006) yang mengemukakan penelitian kuantitatif adalah pendekatan penelitian yang banyak dituntut menguakan angka, mulai dari pengumpulan data, penafsiran terhadap data tersebut, serta penampilan hasilnya. Objek penelitian ini adalah kelelahan karyawan collection dan marketing pada PT. Adira Dinamika Multi Finance Cabang Muara Bungo yang beralamat di Jalan Jenderal Sudirman No. 65 RT. 02 RW.001 Kelurahan Pasir Putih Kecamatan Rimbo Tengah Kabupaten Bungo. Dalam penelitian ini yang menjadi populasi adalah karyawan collection dan marketing pada PT. Adira Dinamika Multi Finance Cabang Muara Bungo yang berjumlah 32 orang. Pengambilan sampel untuk penelitian menurut Arikunto (2006), jika subjeknya kurang dari 100 orang sebaiknya diambil semuanya, jika subjeknya besar atau lebih dari 100 orang dapat diambil $10-15 \%$ atau $20-25 \%$ atau lebih. Sehubungan subjek kurang dari 100 maka seluruh populasi dijadikan sampel yang berjumlah 32 orang.
Tabel 2 Definisi Operasional Variabel

\section{Definisi Operasional}

(X) Beban kerja merupakan suatu yang muncul dari interaksi antara tuntutan tugastugas lingkungan kerja dimana digunakan sebagai tempat kerja, keterampilan dan persepsi dari pekerja. Tarwaka (2010)

(Y) Kelelahan adalah aneka keadaan yang disertai penurunan efisiensi dan ketahanan dalam bekerja.

(Suma'mur, 2009)
Tarwaka (2010)

\section{Indikator}

1. Beban waktu

2. Beban usaha mental

3. Beban tekanan Psikologis

$$
\text { Psikologis }
$$

Tarwaka (2010)

Tarwak

\section{HASIL DAN PEMBAHASAN}

Pada tabel dibawah ini menyajikan karakteristik responden pada karyawan bagian marketing dan collection PT. Adira Dinamika Multi Finance Tbk. Cabang Muara Bungo.

Tabel 3 Karakteristik Responden

\begin{tabular}{|c|c|c|c|}
\hline & $\begin{array}{c}\text { Jenis } \\
\text { Kelamin }\end{array}$ & $\begin{array}{c}\text { Jmlh } \\
\text { Responden }\end{array}$ & $\%$ \\
\hline \multirow[t]{3}{*}{$\mathrm{JK}$} & Laki-laki & 32 & 100 \\
\hline & Perempuan & 0 & 0 \\
\hline & Total & 32 & 100 \\
\hline \multirow[t]{2}{*}{ Usia } & $20-30$ th & 18 & 56,3 \\
\hline & $31-40$ th & 14 & 43,7 \\
\hline
\end{tabular}




\begin{tabular}{llll} 
& 41-50 th & 0 & 0 \\
& $>50$ th & 0 & 0 \\
Total & 32 & 100 \\
Pndd & SMA & 21 & 65,6 \\
& D3 & 2 & 6,3 \\
& S1 & 9 & 28,1 \\
& S2 & 0 & 0 \\
& Total & 32 & 100 \\
LK & $1-5$ th & 24 & 75 \\
& $6-10$ th & 8 & 25 \\
& $11-15$ th & 0 & 0 \\
& $>15$ th & 0 & 0 \\
Total & 32 & 100 \\
\hline
\end{tabular}

Karyawan bagian marketing dan collection seluruhnya laki-laki dan proporsi karyawan PT. Adira Dinamika Multi Finance Tbk. Cabang Muara Bungo didominasi oleh karyawan laki-laki. Hal ini disebabkan perusahaan ini bergerak dibidang pembiayaan kendaraan roda dua dan elektronik. Pembiayaan adalah jasa pemberian kredit, sehingga perusahaan membutuhkan para karyawan yang tangguh di lapangan untuk mencapai target pembiayaan. Karyawan perempuan mayoritas bertugas di bagian administrasi dan kasir/teller sehingga hanya dibutuhkan sedikit karyawan dalam dalam rangka mencapai tujuan perusahaan.

Berdasarkan usia, maka jumlah responden terbesar adalah responden yang berumur antara 20-30 tahun yakni sebanyak 18 orang atau sebesar 56,3\%. Sehingga dapat dikatakan bahwa rata-rata pegawai/karyawan bagian marketing dan collection PT. Adira Dinamika Multi Finance Tbk. Cabang Muara Bungo yang umurnya masih tegolong muda dan produktif. Hal ini dapat lebih menunjang pencapaian target pembiayaan perusahaan.

Karakteristik responden yang berdasarkan tingkat pendidikan yang ditunjukkan pada tabel diatas, dari 32 orang responden terdapat 20 orang atau $66,7 \%$ yang berpendidikan SMA/sederajat, dan terdapat 8 orang atau $26,6 \%$ yang berpendidikan S1. Hal ini menunjukkan bahwa tingkat pendidikan tidak menjadi perhatian bagi karyawan bagian collection, karena tugas penagihan terhadap tunggakan lebih memerlukan keberanian dan ketegasan, berbeda dengan bagian marketing yang memerlukan petugas pemasaran yang baik, sehingga pendidikan yang lebih tinggi membuat seseorang dianggap memiliki kemampuan yang lebih. selanjutnya dengan jenjang pendidikan akan memengaruhi kinerja karyawan. Dimana semakin tinggi pendidikan karyawan yang bekerja maka karyawan akan semakin memiliki wawasan yang luas dalam penanganan pekerjaan.

Pada tabel diatas dari 32 responden terdapat 24 responden atau sebesar $75 \%$ telah bekerja selama 1-5 tahun. Kemudian yang bekerja selama selama $6-10$ tahun sebanyak 8 responden atau sebesar $25 \%$. Lama bekerja pada sebuah perusahaan akan memengaruhi tingkat kematangan seseorang dalam bekerja. Hal ini menunjukkan bahwa pada bagian marketing dan collection diisi oleh karyawan baru dan mengindikasikan bahwa tingkat perputaran karyawan yang tinggi. Kebanyakan karyawan marketing dan collection yang memenuhi target akan mendapatkan promosi jabatan yang lebih cepat, sedang karyawan yang sering tidak tercapai target akan cepat bosan dan pindah pekerjaan.

Uji Validitas dan Reliabilitas. Uji validitas dilakukan untuk menilai seauh mana suatu alat ukur diyakini dapat dipergunakan untuk mengukur suatu pernyataan dalam kuesioner. Valid berarti item-item yang ada dapat digunakan untuk mengukur apa yang harusnya diukur (Sugiyono, 2015). Nilai validitas dapat dilihat pada kolom corrected-item total correlation, nilai tersebut merupakan nilai

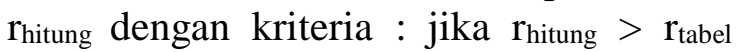
maka butir pernyataan tersebut dinyatakan valid, tetapi sebaliknya jika $r_{\text {hitung }}<r_{\text {tabel }}$ maka item pernyataan kuesioner dinyatakan tidak valid. Hasil uji validitas dari seluruh item pernyataan mengukur 
masing-masing variabel penelitian dinyatakan valid. Hal ini dapat dilihat bahwa $\mathrm{r}_{\text {hitung }}>\mathrm{r}_{\text {tabel }}$ dimana nilai $\mathrm{r}_{\text {tabel }}$ untuk 32 orang adalah 0.349 .

Reliabilitas berarti suatu nilai yang menunjukkan konsistensi suatu alat pengukur di dalam mengukur reabilitas item pertanyaan dalam kuesioner adalah dengan menggunakan koefisien Cronbach's Alpha. Item pernyataan dalam kuesioner dinyatakan reliabel jika memiliki nilai koesfisien Cronbach's Alpha lebih besar dari 0.60 (Sugiyono, 2015).

Tabel 4. Hasil Uji Reliabilitas

\begin{tabular}{cccc}
\hline & Cronbach's & Reliabilitas & Ket. \\
\hline X & 0.783 & 0.60 & Reliabel \\
Y & 0.805 & 0.60 & Reliabel \\
\hline
\end{tabular}

Sumber: data primer yang diolah, 2017

Berdasarkan tabel di atas, hasil pengujian data menunjukkan setiap butirbutir pernyataan pada masing-masing variabel penelitian mempunyai Cronbach's Alpha > 0.60 sehingga seluruh butir-butir pernyataan pada masing-masing variabel penelitian dinyatakan reliabel dan dapat disebarkan kepada responden untuk dijadikan sebagai instrumen penelitian.

Uji Regresi Linear Sederhana. Untuk mengetahui pengaruh atau hubungan variabel bebas (X) yaitu beban kerja terhadap variabel terikat $(Y)$ yaitu kelelahan kerja maka digunakan bantuan software SPSS versi 22. untuk mendapatkan akurasi data yang lebih baik.

$$
\mathrm{Y}=0.645+1.367 \mathrm{X}+\mathrm{e}
$$

Berdasarkan persamaan tersebut dapat dijelaskan sebagai berikut:

Tabel 5. Hasil Uji Regresi Linear Sederhana

Unstandardized Coefficients

\begin{tabular}{lc} 
Model & B \\
\hline 1 (Constant) & .645 \\
beban_kerja & 1.367 \\
\hline
\end{tabular}

a. Dependent Variable: kelelahan_kerja
Berdasarkan hasil pengolahan data seperti terlihat pada tabel diatas pada kolom Unstandardized Coefficients bagian B diperoleh persamaan regresi linear sederhana sebagai berikut; (1) Konstanta (a) $=0.645$ ini mempunyai arti bahwa jika variabel beban kerja (X) dianggap tidak ada (nol) maka kinerja karyawan (Y) sebesar nilai 0.645. (2) Koefisien Regresi Sederhana $(B)=1.367$ ini mempunyai arti bahwa jika variabel beban kerja meningkat satu satuan, maka kelelahan kerja karyawan akan meningkat sebesar 1.367 satuan.

Uji Hipotesis. Uji t bertujuan untuk mengetahui besarnya pengaruh variabel independen secara individual (parsial) terhadap variabel dependen. Nilai thitung diperoleh dengan menggunakan software SPSS versi 22 for windows, kemudian akan dibandingkan dengan nilai $t_{\text {tabel }}$ ada tingkat $\mathrm{a}=5 \%$ yakni diperoleh dengan derajat bebas $\mathrm{df}=$ jumlah sampel-2 dan tingkat signifikansi sebesar alpha 5\% jadi t tabel dengan pengujian 1 sisi hasil diperoleh untuk t tabel sebesar 2.042

\section{Tabel 6. Hasil Uji Regresi Linear Sederhana}

Coefficients $^{\mathrm{a}}$

\begin{tabular}{llrr}
\multicolumn{2}{l}{ Model } & \multicolumn{1}{c}{$\mathrm{t}$} & \multicolumn{1}{c}{ Sig. } \\
\hline 1 & (Constant $)$ & .182 & .857 \\
& beban_kerja & 9.706 & .000 \\
\hline
\end{tabular}

a. Dependent Variable: kelelahan_kerja

Berdasarkan tabel di atas dapat disimpulkan dari hasil uji parsial variabel beban kerja terhadap kelelahan kerja memiliki nilai $t_{\text {hitung }}>\mathrm{t}_{\text {tabel }}$ sebesar $9.706>$ 2.042, maka keputusannya adalah H0 ditolak Ha diterima artinya bahwa variabel beban kerja memiliki pengaruh terhadap kelelahan kerja karyawan bagian collection dan marketing pada PT. Adira Dinamika Multi Finance Cabang Muara Bungo. Dengan demikian semakin tinggi beban kerja yang diberikan perusahaan maka 
akan meningkatkan kelelahan kerja karyawan.

Pengujian Koefisien Determinasi. Koefisien Determinan $\left(\mathrm{R}^{2}\right)$ bertujuan untuk mengukur seberapa jauh kemampuan model dalam menerangkan variasi variabel independen. Dalam output SPSS, koefisien determinasi dapat dilihat pada tabel sebagai berikut:

Tabel 7 Hasil Uji Koefisien Determinan $\left(\mathrm{R}^{2}\right)$

\begin{tabular}{lcrr}
\hline Model & $\mathrm{R}$ & R Square & \multicolumn{2}{c}{$\begin{array}{c}\text { Adjusted } \mathrm{R} \\
\text { Square }\end{array}$} \\
\hline 1 & $.871^{\mathrm{a}}$ & .758 & .750 \\
\hline
\end{tabular}

a. Predictors: (Constant), Beban Kerja

Berdasarkan hasil uji determinasi (R2) dapat disimpulkan bahwa memiliki kemampuan variabel beban kerja dalam menerangkan variasi variabel kelelahan kerja karyawan sebesar $75,8 \%$ dan sisanya $24,2 \%$ dapat dijelaskan oleh faktor-faktor lain diluar penelitian ini. Hal ini menunjukkan bahwa kelelahan kerja karyawan suatu perusahaan dapat meningkat apabila beban kerja yang diberikan perusahaan tinggi.

Dari hasil pengolahan data diperoleh $\mathrm{t}$ hitung lebih besar dari $\mathrm{t}$ tabel, berarti ada pengaruh positif dan signifikan antara beban kerja dengan kelelahan kerja karyawan. Hal ini sesuai dengan teori yang dikemukan oleh Hasibuan (2006) bahwa kelelahan merupakan salah satu indikator dari besarnya beban kerja yang harus ditangung seorang karyawan. Banyak kasus terjadi di Indonesia bahwa pihak perusahaan tidak mampu memperhitungkan kemampuan yang mampu diemban seorang karyawan untuk menyelesaikan pekerjaannya. Pimpinan tidak menyadari bahwa beban kerja yang berat berdampak negatif terhadap kinerja karyawan. Dampak negatif beban kerja tersebut antara lain tidak tercapainya target yang telah ditetapkan, rendahnya kualitas kerja karyawan, meningkatnya tingkat kelelahan karyawan yang selanjutnya akan berdampak pada tingkat absensi atau bahkan meningkatnya perpindahan karyawan.

\section{PEMBAHASAN}

Berdasarkan pengolahan data yang telah dilakukan terhadap variabel beban kerja diketahui jawaban responden berdasarkan beban kerja sebagian besar responden setuju terhadap 6 pernyataan yang berkaitan dengan beban kerja dengan rata-rata skor 4,2 atau berkategori sangat tinggi, dapat disimpulkan bahwa beban kerja karyawan bagian collection dan marketing pada PT. Adira Dinamika Multi Finance Cabang Muara Bungo sangat tinggi. Hal ini dikarenakan karyawan bagian collection dan marketing harus menyelesaikan target kerja yang telah ditetapkan perusahaan, sementara kondisi ekonomi masyarakat yang masih lesu menyebabkan target tersebut sulit dicapai, baik bagian marketing dengan target pembiayaan baru maupun bagian collection dengan target pengembalian pembiayaan.

Berdasarkan pengolahan data terhadap variabel kelelahan kerja diketahui bahwa jawaban responden berdasarkan kelelahan kerja sebagian besar responden setuju terhadap 8 pernyataan yang berkaitan dengan kelelahan kerja dengan rata-rata skor 4,2 atau berkategori tinggi, dapat disimpulkan bahwa kelelahan kerja karyawan bagian collection dan marketing pada PT. Adira Dinamika Multi Finance Cabang Muara Bungo tinggi. Hal ini dikarenakan karyawan bagian collection dan marketing memiliki beban kerja yang tinggi, sementara kondisi ekonomi masyarakat yang masih lesu menyebabkan karyawan menjadi lelah dalam mencapai target tersebut, baik bagian marketing dengan target pembiayaan baru maupun bagian collection dengan target pengembalian pembiayaan.

Berdasarkan hasil uji parsial variabel beban kerja terhadap kelelahan kerja 
memiliki nilai $t_{\text {hitung }}>\mathrm{t}_{\text {tabel }}$ sebesar $9.706>$ 2.042, maka keputusannya adalah H0 ditolak Ha diterima artinya bahwa variabel beban kerja memiliki pengaruh terhadap kelelahan kerja karyawan bagian collection dan marketing pada PT. Adira Dinamika Multi Finance Cabang Muara Bungo. Dengan demikian semakin tinggi beban kerja yang diberikan perusahaan maka akan meningkatkan kelelahan kerja karyawan. Dari hasil pengolahan data diperoleh $\mathrm{t}$ hitung lebih besar dari t tabel, berarti ada pengaruh positif dan signifikan antara beban kerja dengan kelelahan kerja karyawan. Hal ini sesuai dengan teori yang dikemukan oleh Hasibuan (2006) bahwa kelelahan merupakan salah satu indikator dari besarnya beban kerja yang harus ditangung seorang karyawan. Banyak kasus terjadi di Indonesia bahwa pihak perusahaan tidak mampu memperhitungkan kemampuan yang mampu diemban seorang karyawan untuk menyelesaikan pekerjaannya. Pimpinan tidak menyadari bahwa beban kerja yang berat berdampak negatif terhadap kinerja karyawan. Dampak negatif beban kerja tersebut antara lain tidak tercapainya target yang telah ditetapkan, rendahnya kualitas kerja karyawan, meningkatnya tingkat kelelahan karyawan yang selanjutnya akan berdampak pada tingkat absensi atau bahkan meningkatnya perpindahan karyawan.

\section{SIMPULAN}

Berdasarkan hasil penelitian dan pembahasan pada bab sebelumnya, maka dapat ditarik kesimpulan sebagai berikut; (1) Berdasarkan hasil pengolahan data, hasil uji parsial variabel beban kerja terhadap kelelahan kerja memiliki nilai $\mathrm{t}_{\text {hitung }}>\mathrm{t}_{\text {tabel }}$ sebesar $9.706>2.042$, maka keputusannya adalah $\mathrm{H} 0$ ditolak $\mathrm{Ha}$ diterima artinya bahwa variabel beban kerja memiliki pengaruh terhadap kelelahan kerja karyawan bagian collection dan marketing pada PT. Adira Dinamika Multi Finance Cabang Muara Bungo.
Dengan demikian semakin tinggi beban kerja yang diberikan perusahaan maka akan meningkatkan kelelahan kerja karyawan. (2) Berdasarkan hasil uji determinasi $\left(\mathrm{R}^{2}\right)$ dapat disimpulkan bahwa memiliki kemampuan variabel beban kerja dalam menerangkan variasi variabel kelelahan kerja karyawan sebesar 75,8\% dan sisanya $24,2 \%$ dapat dijelaskan oleh faktor-faktor lain diluar penelitian ini. Hal ini menunjukkan bahwa kelelahan kerja karyawan suatu perusahaan dapat meningkat apabila beban kerja yang diberikan perusahaan tinggi.

\section{DAFTAR PUSTAKA}

Ambar. 2006. Hubungan Antara Kelelahan Kerja Dengan Produktivitas Kerja karyawan. Skripsi. Fakultas Kesehatan Masyarakat. Universitas Negeri Malang.

Arikunto S. 2006. Prosedur Penelitian Suatu Pendekatan Praktik, Ed Revisi VI. Jakarta. Penerbit PT Rineka Cipta

Budiono, A.M Sugeng, dan Pusparini A. 2003. Keselamatan Kerja dan Pencegahan Kecelakaan Kerja. Bunga Rampai Hiperkes dan Keselamatan Kerja. Edisi ke-2. Semarang. Universitas Diponegoro.

Hasibuan, Malayu S.P, 2006, Manajemen Dasar, Pengertian, dan Masalah,Edisi Revisi, Jakarta. Bumi Aksara

Munandar, M. 2001. Budgeting, Perencanaan Kerja Pengkoodinasian Kerja Pengawasan Kerja. Edisi Pertama. Yogyakarta. BPFE Universitas Gajah Mada.

Nurmianto, Eko. 2003. Ergonomi Konsep Dasar Dan Aplikasinya. Surabaya: Guna Widya

Sugiyono. 2015. Metode Penelitian Pendidikan (Pendekatan Kuantitatif, Kualitatif dan R\&D). Bandung. Penerbit CV. Alfabeta

Suma'mur. 2009. Hiegiene Perusahaan dan Keselamatan Kerja. Jakarta. CV Sagung Seto 
Tarwaka. 2010. Ergonomi Industri.Dasar-

Dasar Pengetahuan Ergonomi dan Aplikasi di Tempat Kerja. Edisi Kedua. Surakarta. Harapan Press

Wignjosoebroto, S. 2000. Ergonomi, Studi Gerak dan Waktu Teknik Analisis untuk Peningkatan Produktivitas Kerja. Edisi I cetakan Kedua. Surabaya. Pen erbit Guna widya 